УДК 323.325:3:631.11.001.3

(C) 2012

Макаренко Ю. П., кандидат економічних наук

ННЦ «Інститут аграрної економіки»

\title{
ІДЕНТИФІКАЦІЯ ФЕРМЕРСЬКИХ ГОСПОДАРСТВ ЗА СУТНІСТЮ ТА РОЗМІРАМИ
}

\section{Рецензент - доктор економічних наук В. В. Писаренко}

Визначена сутність фермерських і селянських господарств за ознаками виробничих одиниць, найму прачівників, рівня товарності; встановлено тотожність понять «селянин» $i$ «фермер». Ідентифіковано фермерські господарства за критеріями: власник ферми, управління і виробничого процесу, інтеграції з іншими формами господарювання, функціях контролю за виробництвом, розмірами підприємства. Диференційовано малі аграрні підприємства за розмірами землекористування.

Ключові слова: фермерство, селянське господарство, власник, розміри землекористування, сімейні господарства, наймана прачя, товарні господарства.

Постановка проблеми. У сільському господарстві невеликі трудові виробничі одиниці називаються селянськими господарствами. В економічній літературі окремі науковці вважають, що фермерські господарства не тотожні селянським. Головним критерієм такої відмінності виступає використання найманої праці. Зокрема селянські господарства можуть наймати працівників, але лише для використання обмеженого виду сільськогосподарських робіт і на тимчасовій, сезонній основі. Постійними й основними учасниками виробництва є власники селянських господарств і члени їхніх сімей.

Фермерські ж господарства використовують у своєму виробничому процесі найманих працівників на постійній основі. До того ж за власниками фермерських господарств і членами їхніх сімей потенційно мають зберігатися лише функції управління й організації виробництва [3]. Тому встановлення тотожності цих господарств обумовлюється низкою факторів, що мають як подібні, так і відмінні ознаки. Фермерські господарства за розмірами відносять частіше до сектора малих підприємств. Однак цей сектор неоднорідний, і відносна життєздатність більшості дрібних і малих підприємств пояснюється не лише їх державною підтримкою, а й формуванням нової моделі аграрної сфери економіки в контексті зосередження виробництва у високоефективних інноваційних агроструктрурах. Актуальність і доціль- ність дослідження вказаних вище питань й обумовила написання даної статті.

Аналіз основних досліджень і публікацій, у яких започатковано розв'язання проблеми. Значний внесок у вивчення питань оптимальних розмірів і класифікації малих аграрних господарств внесли В. К. Збарський [1], Л. Ю. Мельник [2], С. О. Рубахін [3], М. О. Тонюк [5], М. Туган-Барановський [6], О. В. Чаянов [7], T. Яворська [8] та інші. Водночас потребують вирішення такі питання як встановлення критеріїв ідентифікації фермерських і селянських господарств на сучасному етапі їх розвитку; класифікаційні ознаки поділу малих аграрних господарств і виділення в їх складі мікропідприємств.

Мета дослідження полягає у вивченні критеріїв ідентифікації фермерських господарств за сутністю i розмірами, а також у визначенні їх місця в процесі диференціації малого аграрного бізнесу.

Результати дослідження. Останнім часом провідні науковці не без підстав стверджують, що за такого підходу до визначення сутності поняття «фермерське господарство» навіть у США 3/4 сімейних господарств не вписуються у статус фермерських, оскільки не наймають працівників взагалі. Якщо прийняти точку зору С. О. Рубахіна про те, що фермерськими є лише господарства, які наймають працівників на постійній основі, а сам фермер виконує лише функції господаря-менеджера, то фермерські господарства займали б досить скромне місце. Якщо йдеться про «господарство» як економічно самостійну виробничу одиницю у ринковій економіці, то в даному аспекті фермерські й селянські господарства не відрізняються один від одного. I перші, і другі виступають як сільськогосподарські виробники, незалежно від того, наймають вони працівників тимчасово, постійно чи взагалі цього не практикують. Головне - вони виробляють аграрну продукцію. Те ж саме стосується й товарності господарств. Взагалі $з$ того часу, як виникло товарне виробництво, «чистих» натуральних господарств практично не існує, адже 
власники будь-якого господарства купують на ринку ті чи інші засоби виробництва або життєві блага. Тим більше не вважаються такими господарствами ті, які продають частину валової продукції, - бо це вже натурально-товарні господарства. Такі критерії як «рівень товарності», «використання найманої праці» варто використовувати у відповідній класифікації фермерських господарств. У Росії й Україні сімейні господарства в аграрній сфері завжди називалися селянськими. Саме тому, напевне, не випадково спочатку чинним законодавством України ті селянські господарства, які мали статус юридичної особи, називали селянськими (фермерськими) господарствами, хоча в пізнішій редакції Закону - виключно «фермерськими».

Водночас, можливо, обгрунтованою точкою зору є й та, згідно 3 якою поняття «селянин» $\mathrm{i}$ «фермер» мають різне значення. Перше з них більш загальне й характеризує людину, яка працює у сільському господарстві. Даний термін не акцентує увагу на відносинах власності та господарювання. Селянин - це і кріпак, і вільний землероб, i колгоспник, i працівник радгоспів, i найманий працівник. Коли мова йде про селянське господарство, то мається на увазі селянин, який є його власником [2, с. 44-46]. У «Словнику іноземних слі» поняття «фермер» [англ. farmer] означає «власник сільськогосподарського підприємства, ферми» [4, с. 524].

Отже, якщо йдеться про аграрне господарство та його власника, то поняття «селянське» і «фермерське» господарство виступають як тотожні.

У США, до речі, «ферма» - синонім будьякого аграрного формування, незалежно від його організаційно-правової форми. Інакше кажучи, в США «ферма» - узагальнене поняття, що охоплює «сімейні ферми», «партнерства», «корпорації» (сімейного й несімейного типу), «сільськогосподарські виробничі кооперативи» та інші агроструктури. У США й інших країнах переважна більшість фермерських господарств - це сімейні ферми.

Специфічні критерії їхньої ідентифікації у науковій літературі визначаються зазвичай у такому трактуванні:

- власником ферми є одна особа або сім'я (як один власник);

- управління i виробничий процес здійснюються в основному самим фермером і його сім'єю;

- тісна інтеграція між домашнім господарством і бізнесом;

- функція контролю належить фермеру.
Важливо зазначити, що жодна 3 класифікацій аграрних господарств не привертала до себе такої пильної уваги науковців, як розподіл їх за розмірами. Зумовлено це тією обставиною, що ефективність сільськогосподарських підприємств визначається багатьма факторами, одним iз яких $\epsilon$ рівень концентрації виробництва або розміри підприємства.

Розмір підприємства - це рівень концентрації в ньому виробничих ресурсів і обсягів виробленої продукції. Відповідно, він визначається двома групами показників:

по-перше, ті, що характеризують виробничий потенціал (розміри основних і обігових фондів; кількість працівників; розміри земельних площ);

по-друге, показники, що визначають результати виробництва - обсяги виробленої продукції (валової, товарної); розміри одержаного прибутку тощо.

У контексті економічних досліджень розміри господарств досліджуються передусім як чинник, що впливає на ефективність господарської діяльності агрогосподарств.

В аграрній економічній науці це питання актуалізувалося ще на рубежі XIX-XX століть. До того ж у практичному плані йшлося про різні відповіді на запитання: які аграрні господарства мають переваги - великі чи малі.

Перші, як правило, є капіталістичними (використовують найману працю). Другі - сімейнотрудові.

Порівнюючи великі капіталістичні підприємства 3 дрібними селянськими, М. ТуганБарановський зазначав: «Таким чином, зіставляючи порівняну потужність і стійкість крупного капіталістичного і дрібного трудового сільського господарства у їх боротьбі маємо сказати, що в наш час перевага схиляється швидше у бік дрібного господарства. Цьому аж ніяк не суперечить той факт, що капіталістичне сільське господарство в багатьох країнах широко розповсюджене, а в деяких із них є навіть єдиною формою сільського господарства (наприклад, в Англії)» [6, с. 168].

Дрібне трудове господарство, як зазначав О. В. Чаянов, є більш стійким і живучим, аніж крупне капіталістичне господарство. Водночас він не заперечував того факту, що у крупного й навіть крупнокапіталістичного господарства є позитивні ознаки, зокрема:

1) у крупних господарствах зберігається багато праці, зв'язаної з «домоведенням»;

2) менше доріг, меж і огорож;

3) менші затрати інвентарю і тяглової сили 
тварин на кожну десятину;

4) між робітниками встановлюється розподіл праці, - вона стає більш продуктивною;

5) $є$ можливість повніше застосовувати відкриття й рекомендації науки, новітні знаряддя праці.

Однак для крупного капіталістичного господарства характерні кілька суттєвих недоліків, які, власне, затіняють його позитивні ознаки.

По-перше, великому капіталістичному господарству необхідний капітал: однак капітал іде туди, куди йому вигідно. У сільському господарстві капітал менш ефективний, він приносить мало прибутку, поскільки витрачається на машини, споруди, будівлі тощо. Між іншим, основні засоби виробництва в дії лише півроку, а то й менше, - в інший час вони залишаються мертвим капіталом. I кожен розуміє, що це означає для капіталіста. Крім того, капітал у сільському господарстві забезпечує не лише менший прибуток, але й не гарантує будь-якого прибутку (мається на увазі залежність сільського господарства від погодніх умов). Капіталістичному сільському господарству необхідні наймані працівники. Однак останнім вигідніше працювати на фабриці: в сільському господарстві вони отримують досить низьку заробітну плату й потрібні лише півроку. Тому капіталістичне господарство все сильніше відчуває нестачу робочих рук. Крім усього, виявляється, що наймана праця у сільському господарстві відзначається меншою сумлінністю і продуктивністю.

Інша річ - трудове господарство, яке не має недоліків, характерних капіталістичному господарству. Не дивлячись на всі тяжкі умови його існування, воно існує і зміцнюється. Іншими словами, воно стабільне і живе. І це не тільки в нас. Досвід доводить, що виживає й міцніє саме трудове дрібне господарство - і в Бельгії, і в Нідерландах, і в Франції. Ось чому ми переконані, що майбутній земельний порядок повинен базуватися саме на трудових, а не на капіталістичних господарствах. I якщо в промисловості фабрика «побиває» дрібного виробника, то у сільському господарстві цього немає, - крупне капіталістичне господарство тут «побивається» трудовим. Інша справа, в промисловості, де капітал працює безперервно й приносить великий доход. Ось чому капітал надає перевагу промисловості [7, с. 47-49].

Потрібно враховувати, що О. В. Чаянов був визнаним лідером організаційно-виробничої школи. Її представники не обмежувалися мікроекономічним аналізом приватно-трудових селянських господарств. Більше того, вони вважали, що господарська діяльність останніх обмежена певними організаційними рамками. Інакше кажучи, кожне господарство в плані підвищення ефективності має межу, за якою даний процес зупиняється. Стійкий економічний розвиток i підвищення ефективності селянського господарства можливі за умови розвитку таких процесів, як їхня кооперація, інтеграція з іншими сферами виробництва, досягнення оптимальних розмірів. Тому сімейні селянські господарства мають зосередитися на безпосередньо виробничих процесах (вирощуванні рослин і тварин). Подальший «рух» їхньої продукції до кінцевого покупця (власне продукції чи у вигляді сировини) повинен стати об'єктом різних видів кооперативів самих селян (переробка, зберігання, реалізація й навіть постачання засобів виробництва та кредитування). Такі кооперативи можуть протистояти капіталістичній еволюції селянських господарств і водночас створювати умови для прогресивного розвитку сільського господарства.

Виходячи 3 цих критеріїв, сільськогосподарські підприємства можна розподіляти на більшу або меншу кількість груп. Найбільш узагальнений підхід - це їх розподіл на три групи: великі, середні й малі. До того ж не обов'язково використовувати систему показників - для агроструктур (передусім землеробського напряму) достатньо використати два 3 них, а саме:

1) розміри землекористування;

2) виробництво валової або товарної продукціï.

В економічній науці й практиці стосовно малого бізнесу взагалі відсутнє уніфіковане визначення. Використовуються понад 50 різних статистичних показників, що характеризують малі підприємства. Переважають кількісні критерії чисельність працюючих, річний обсяг господарського обороту i т. д. Широко застосовуються якісні критерії, такі, наприклад, як маса прибутку, прямий особистий контакт керівництва 3 виробничим персоналом, клієнтурою, постачальниками, самостійність, жорстка залежність від ближніх ринків і джерел сировини та ін.

У Великобританії, наприклад, до малих відносяться підприємства і фірми 3 кількістю зайнятих близько 200 чоловік у промисловості і близько 25 - в будівництві. У Франції до малих відносяться підприємства і фірми 3 кількістю зайнятих від 10 до 50 чоловік, до ремісничих близько 10 чоловік працюючих. У Болгарії до малих відносяться підприємства з числом зайнятих близько 50 працюючих осіб. У Японії до середніх і дрібних підприємств у видобувній та 
оброблювальній промисловості, на транспорті і в будівництві відносяться підприємства зі статутним капіталом до 0,1 млрд. ієн (близько 700 тис. дол.) і числом працюючих близько 300 чоловік: у оптовій торгівлі, відповідно, - до 30 млн. ієн та близько 100 працюючих, у роздрібній торгівлі та сфері послуг - 10 млн. ієн і 50 працюючих. У ФРН до дрібного і середнього підприємництва відносяться фірми 3 числом зайнятих близько 300 чоловік із річним оборотом до 100 млн. євро.

У разі законодавчого визначення суб'єктів малого і середнього бізнесу в більшості країн частіше всього за максимальний рівень кількості зайнятих приймається 50 осіб для суб'єктів малого та 200-250 осіб - для суб'єктів середнього бізнесу. Серед малих підприємств поширеним $\epsilon$ виокремлення мікропідприємств, до яких, зазвичай, належать малі підприємства 3 кількістю зайнятих близько 10 осіб.

У Законі України «Про внесення змін до деяких законодавчих актів України з питань регулювання підприємницької діяльності» від 18.09.2008 p. №523-VI наводиться визначення суб'єкта малого підприємництва, до якого відносяться фізичні особи, зареєстровані в установленому порядку як суб'єкти підприємницької діяльності, а також юридичні особи - суб'єкти підприємницької діяльності будь-якої організаційно-правової форми та форми власності, - в яких середньооблікова чисельність за звітний період (календарний рік) не перевищує 50 осіб, а обсяг річного валового доходу - 70 млн. гривень. Дія даного закону поширюється й на суб'єкти малого підприємництва, які функціонують у сільському господарстві.

У такому разі в сільському господарстві до малого бізнесу можна віднести майже всі фермерські господарства, особисті селянські господарства і більшість сільськогосподарських підприємств. Підприємства 3 розміром сільськогосподарських угідь 500 га і більше недоцільно відносити до підприємств малого бізнесу у сільському господарстві [8].

Окремими науковцями підтримується позиція, за якої малий бізнес у сільському господарстві диференціюються наступним чином:

I - (до 20 га) - особисті селянські та дрібні фермерські господарства;

II - (від 20 до 100) - сімейні фермерські господарства;

III - (від 100 до 500) - фермерські господарства й сільськогосподарські підприємства різних організаційно-правових форм господарювання.
Водночас зазначається, що у сільському господарстві США американські економісти поділяють ферми на категорії, використовуючи критерій за сумою реалізованої ними продукції (обсяг продажу, тис. дол.):

I - (до 10 тис. дол.) - за умови проживання фермера в сільській місцевості;

II - (від 10 до 40) - дрібні селянські ферми;

III - (від 40 до 250) - сімейна ферма;

IV - (від 250 до 500) - велика сімейна ферма;

$\mathrm{V}$ - (понад 500) - суперферма.

Такий підхід вважається економічно виправданим, оскільки обсяги виробництва та потреби в ресурсах у різних галузях суттєво відрізняються [1].

Відносно сільського господарства України окремі науковці діходять висновку: «...за роки земельної реформи в Україні було створено широкий спектр малих, середніх і великих форм господарювання, які можуть забезпечити розвиток підприємництва у сільському господарстві на ринкових умовах... До великих агроформувань можна віднести сільськогосподарські недержавні і державні підприємства; до середніх фермерські господарства, міжгоспи; до малих особисті селянські господарства.

Досвід розвинених країн підтверджує доцільність такої класифікації, адже вона відображає реальний стан аграрного сектора. Керуючись цим підходом до структури форм господарювання в сільському господарстві, легше зрозуміти специфіку землі, зокрема купівлі-продажу в межах кожної із зазначених форм, тобто сегментацію земельного ринку» [5, с. 74].

Висновки. Безсумнівно, можливі різні підходи щодо класифікації агрогосподарств за розмірами, використання неоднакових критеріїв. Напевне, якщо порівнювати показники площі землекористування та обсяги реалізованої продукції (обсяги продаж), то щодо бізнесових агроструктур слід надати переваги останньому.

Таким чином, фермерське господарство як економічно самостійна виробнича одиниця зазвичай $\epsilon$ трудовим господарством, що має товарний характер і відноситься до малого аграрного бізнесу із розміром сільськогосподарських угідь до 500 гектарів.

Дрібні, сімейні та власне фермерські господарства формуються з урахуванням специфіки діяльності малого аграрного бізнесу.

Як виробники сільськогосподарської продукції, фермерські селянські господарства виступають як тотожні. 


\section{БІБЛІОГРАФІЯ}

1. Збарський В. К. Особисті селянські господарства: місце і роль у продовольчому забезпеченні країни / В. К. Збарський, М. П. Канінський // Агроінком. - 2008. - № 1-2. - С. 27-32.

2. Мельник Л. Ю. Аграрне підприємництво і держава: [монографія]. / Л. Ю. Мельник, П. М. Макаренко, О. А. Любович. - Дніпропетровськ: Пороги, 1999. - $259 \mathrm{c}$.

3. Рубахін С. О. О классификации предприятий частнохозяйственного уклада в сельском хозяйстве // АПК: экономика, управление. - 1997. № 1. - C. 73-76.

4. Словарь иностранных слов. - 14-е изд., испр. М.: Рус. яз., 1987. -608 c.
5. Тонюк M. О. Трансформація відносин власності на землю та землекористування як передумова становлення земельного ринку в Україні / М. О. Тонюк // Економіка АПК. - 2005. - № 4. C. 69-75.

6. Туган-Барановський М. Політична економія. Курс популярний. / Туган-Барановський М. - К. : Наукова думка, 1994. - 263 с.

7. Чаянов А. В. Избранные произведения: Сборник / Чаянов А. В.; [сост. Е. В. Серова]. - М.: Моск. рабочий, 1989. - 368 с.

8. Яворська T. Особливості визначення критеріїв малого бізнесу / Т. Яворська // Аграрна економіка. - 2009. - Т. 2. - № 3-4. 